\title{
Association between seropositivity for Neospora caninum and reproductive performance of beef heifers in the Pantanal of Mato Grosso do Sul, Brazil
}

\author{
Associação entre soropositividade para Neospora caninum e o desempenho reprodutivo \\ de novilhas de corte no Pantanal Sul-Mato-Grossense, Brasil \\ Renato Andreotti ${ }^{1 *}$; Jacqueline Cavalcante Barros ${ }^{1}$; Anselmo Ranier Pereira ${ }^{2}$; Leandra Marla Oshiro ; \\ Rodrigo Casquero Cunha ${ }^{3}$; Leonardo Francisco Figueiredo Neto
}

${ }^{1}$ Empresa Brasileira de Pesquisa Agropecuária - EMBRAPA-Gado de Corte

${ }^{2}$ Médico Veterinário Autônomo

${ }^{3}$ Universidade Federal do Mato Grosso do Sul - UFMS

${ }^{4}$ Departamento de Economia e Administraçáo, Universidade Federal do Mato Grosso do Sul - UFMS

Received January 22, 2010

Accepted March 22, 2010

\begin{abstract}
Neospora caninum is an obligate intracellular parasite that can infect domestic and wild canids, ruminants, and horses. The purpose of this study was to evaluate the association between the presence of antibodies to $N$. caninum and reproductive loss in beef heifers in the South Pantanal region of Mato Grosso, Brazil. A total of 1098 heifers were evaluated from breeding to calving with regard to reproductive performance, and serology for neosporosis was assayed by indirect immunofluorescence reaction. The prevalence of $N$. caninum in cows that had failed to conceive was $22.13 \%$ higher than in those that had conceived $(\mathrm{p}<0.0001)$, indicating a significant correlation between non-conception and presence of anti- $N$. caninum antibodies. The extraction rates for seropositive and seronegative heifers were 28.24 and $50.12 \%$, respectively, with a statistically significant value $(\mathrm{p}<0.0001)$ that showed a decrease of $44 \%$ in the extraction rate of seropositive animals. The results emphasize the importance of diagnosis for monitoring of neosporosis in primiparous cows, and indicators of seropositive females as a factor in strategies for culling the beef cattle herd.
\end{abstract}

Keywords: Reproduction, bovine, diagnostic, abortion, Neospora caninum.

\section{Resumo}

Neospora caninum é um parasita intracelular obrigatório que pode infectar canídeos domésticos e selvagens, ruminantes e equídeos. Neste trabalho estudou-se a associação entre soropositividade para Neospora caninum e perda reprodutiva em novilhas de corte na região do Pantanal Sul-Mato-Grossense. Foram avaliadas 1098 novilhas da estação de reprodução ao nascimento dos bezerros com relação ao desempenho reprodutivo e realizada a sorologia para $N$. caninum através da reaçáo de imunofluorescência indireta. A soroprevalência de $N$. caninum nas vacas que falhara na concepção foi 22,13\% maior que nas que conceberam $(\mathrm{p}<0,0001)$, indicando que há uma correlaçáo significativa entre a não concepção e a presença de anticorpos anti- $N$. caninum. As taxas de desfrute para as novilhas soropositivas e soronegativas para neosporose foram de 28,24 e $50,12 \%$, respectivamente, mostrando uma redução de $44 \%$ na taxa de desfrute de novilhas soropositivas para N. caninum. Ressalta-se a importância do monitoramento do diagnóstico da neosporose em primíparas, e o indicador de fêmeas soropositivas como um fator nas estratégias de descarte no rebanho bovino de corte.

Palavras-chave: Reprodução, bovinos, diagnóstico, aborto, Neospora caninum.

\footnotetext{
${ }^{*}$ Corresponding author: Renato Andreotti

EMBRAPA-Gado de Corte, BR 262, Km 4, CP 154, CEP 79002-970,

Campo Grande - MS, Brasil;

e-mail: andreott@cnpgc.embrapa.br
} 


\section{Introduction}

Neospora caninum is an obligate intracellular parasite that until 1988 was confused with Toxoplasma gondii (LINDSAY; DUBEY; McALLISTER, 1988). Dogs and coyotes are definitive hosts, which eliminate parasite oocytes in their feces. After sporulation, these oocytes are ingested by an intermediary host and form tissular cysts (LINDSAY et al., 1999; McALLISTER et al., 1998; GONDIM et al., 2004).

Neosporosis has emerged as an important disease in bovines worldwide and is related to reproductive loss in these animals, causing abortions and neonatal mortality (ANDERSON et al., 1991; BARR et al., 1991; THORNTON; THOMPSON; DUBEY, 1991; WOUDA et al., 1999). Establishing the diagnosis of neosporosis is therefore important, as a step in re-breeding and possibly switching dams according to their history of abortions (DUBEY; SCHARES; ORTEGA-MORA, 2007).

Besides being associated with bovines, this protozoon has been associated with the occurrence of sporadic disease in other animals species, including sheep (DUBEY; SCHARES; ORTEGA-MORA, 2007), goats (BARR et al., 1992), and horses (MARSH et al., 1996).

The serologic prevalence of $N$. caninum in beef cattle in Canada, as obtained from random samples of confined animals, was $6.5 \%$ positive animals. Prevalence in blood samples from auction animals was $9.0 \%$. As opposed to this low seropositivity, a study on the association between $N$. caninum infection and reproductive performance found that $30 \%$ of the cattle selected for the study were seropositive (HADDAD; DOHOO; VANLEEWEN, 2005). As for groups in which abortion had been documented and no antibodies for other pathogens were found, between 17 and $45 \%$ of aborted fetuses were seropositive for $N$. caninum (PITEL et al., 2001).

The presence of positive serology for $N$. caninum in beef cattle in the State of Mato Grosso do Sul (MS), Brazil has been established as 30\% in heifers (ANDREOTTI et al., 2004) and 14.9\% in cows (OSHIRO et al., 2007). An association between seropositivity and abortion was found in $69.8 \%$ of bovine herds (OSHIRO et al., 2007). Seropositivity was $29.5 \%$ for anti- $N$. caninum antibodies in embryo-receptor heifers of beef cattle raised extensively (PAZ; LEITE; ROCHA, 2007).

Most abortions due to infection by Neospora are diagnosed between 3 and 8 months of gestation, although abortions that occur early in the pregnancy are more difficult to diagnose due to a lack of fetal material necessary for analysis (INNES, 2007).

As for vertical transmission of $N$. caninum, infected heifers that become healthy adults may transmit the agent to the fetus, which is especially vulnerable, thereby maintaining the parasite in the herd (ANDERSON et al., 1997; INNES et al., 2005). Transplacental transmission has been reported in at least $36.8 \%$ of neosporosis-positive heifers and may reach $100 \%$ in experimental infections (THURMOND; HIETALA, 1996; WILLIAMS, et al., 2000; INNES, et al., 2005; VIANA et al., 2008).

Here we studied the association between $N$. caninum antibodies and reproductive loss in heifers of beef cattle of the south Pantanal region of Mato Grosso State, Brazil. Our results allow us to measure the bottleneck of the reproductive efficiency in these animals.

\section{Material and Methods}

\section{Study area}

The study was done in a farm located in the South Pantanal region of Mato Grosso State, Brazil (2006' 05” S and 56 47' 43” W). It is an area of plains subjected to dry and flood seasons and suffers periodic inundations. The climate is hot and rainy in the summer and dry and pleasant in the winter, with average temperatures of 32 and $21{ }^{\circ} \mathrm{C}$, respectively. The ground has low natural fertility (CADAVID GARCIA, 1986).

The reproductive system on the farm is comprised of breeding, rebreeding, and fattening. The areas dedicated to cattle have cultivated pastures of marandu-grass (Brachiaria brizantha cv. Marandu) and guinea-grass (Panicum maximum). The field system is characterized by a low number of pastures and a defined season for mating in which andrologic examination of the bulls is done and separate handling is adopted for heifers and reproductive cows.

\section{Sample collection}

A total of 1098 Nelore heifers aging around 24 months and with average weight of $259.14 \mathrm{~kg}$ were evaluated. The mating season regime was artificial insemination with repeated bulls (1:35) during the period of November 2007 and March 2008. Diagnosis of gestation was based on a rectal palpation done around 60 days after mating. Animals were followed during the reproductive regime until the calves were one month of age.

Information about the herds was collected based on the handling routine at the farm. We collected blood samples from cows twice, once at the diagnosis of gestation, around 60 days after mating, and again a month after delivery. Blood samples were also collected from heifers when they were around one month old. After identification, sera were kept in $-20{ }^{\circ} \mathrm{C}$ until serologic tests were done.

\section{Indirect immunofluorescence reaction (RIFI)}

Samples were examined by RIFI to detect the presence of antibodies against $N$. caninum. The antigen was produced in cultures of tachyzoites of $N$. caninum, strain NC-1 (DUBEY et al., 1988) in Vero cells (OLIVEIRA et al., 2004). A commercial conjugate anti-IgG bovine (Sigma) was used at a dilution of 1:10,000 and the samples were tested at a dilution of 1:50 (PARÉ; THURMOND; HIETALA, 1996). A positive and negative serum sample was included in each slide.

\section{Statistical analysis}

To determine sample size we used the population proportion estimate $\left(\mathrm{n}=(\mathrm{Z} \alpha / 2)^{2} .0 .25 / \mathrm{E}\right)$ according to Levine, Berenson e Stephan (2000), with 95\% of confidence and 3\% error. A total of 1098 primiparous Nelore heifers were analyzed.

For statistical analysis of prevalence results of the neosporosis diagnosis in pregnant heifers, as well as of the abortion or conception (birth) prevalence, we used $2 \times 2$ contingency tables as determined by chi-square $\left(\chi^{2}\right)$ test (SAMPAIO, 2007), using the statistical program MedCalc ${ }^{\circledast}$ 8.0.0.0. 


\section{Results and Discussion}

There is no consensus for a cut-off value to be used as reference for the diagnosis of neosporosis. Additionally, this value could be affected by the animal age or disease stage, the strategy used for diagnosis, and laboratory conditions (ALVAREZ-GARCIA et al., 2003; Von BLUMRÖDER et al., 2004; DUBEY; SCHARES, 2006). Serological tests for the identification of infected animals may require higher sensitivity and lower cut-off than suggested for the diagnosis of bovine abortion. For these reasons we defined a cut-off value that would provide greater sensitivity to the test (1:50).

Cow blood serum samples of the first and second collection by RIFI showed similar results, with only three sera being converted into positive in the second collection. Therefore, we considered the information from animals with two positive results for the serological analysis in order to co-relate the results with births.

The diagnosis of gestation by palpation verified a total of 546 pregnant cows, which corresponded to $49.73 \%$ of the whole herd. The diagnosis of gestation in the positive and negative categories for $N$. caninum serology showed significant difference $(\mathrm{p}<0.0001)$ between groups (Table 1$)$.

Loss of pregnancy was $15 \%$ higher in seropositive cows (55.89\%) as compared to loss in $N$. caninum seronegative cows ( $40.88 \%)$, showing that in this bovine herd the presence of positive $N$. caninum serology is a relevant factor for female reproduction. It has been shown that a seropositive cow that suffers an abortion has a 5.7 times greater risk of having an abortion in subsequent gestations (THURMOND; HIETALA, 1997).

During the period between the beginning of the mating season and the gestation diagnosis in cows negative for $N$. caninum, we verified a loss of $40.88 \%$, with an additional percentage of $9 \%$ of loss until birth. In cows positive for $N$. caninum, loss in the first period was $55.89 \%$, and in the second it was $15.87 \%$. The results revealed a higher impact of reproductive loss in both categories between the beginning of the mating season and the diagnosis of gestation.

Seroprevalence of $N$. caninum in cows that did not conceive was $22.13 \%$ higher than in those that conceived $(p<0.0001)$, which indicates a significant correlation between not conceiving and the presence of anti- $N$. caninum antibodies. These results reveal that the loss between the gestation diagnosis period and conception in seropositive cows was $36 \%$, while in seronegative cows it was $15.23 \%$, indicating that positive serology for $N$. caninum affects the conception ratio.

One of the main symptoms of seropositivity in bovines is abortion, which may occur due to activation of tachyzoites and their migration to the uterus (DUBEY; SCHARES; ORTEGA-MORA, 2007). Thus, the association between positive serology for $N$. caninum and abortion during the reproductive season, when compared to negative cows, can confirm the presence of this disease in this herd. The positive serology suggests the existence of antibody production from tachyzoites and the presence of at least the latent form, bradyzoites, which remains in the host for the rest of its life.

The prevalence of $N$. caninum in calves in relation to heifers is shown in Table 2. The highest prevalence of seropositive calves among those born from $N$. caninum seropositive heifers was statistically significant $(\mathrm{p}<0.0001)$, suggesting the occurrence of vertical transmission of neospora between the mother and calves, although it was not possible to determine the ratio of vertical transmission in this herd.

There were $38.4 \%$ more $N$. caninum seropositive calves born from seropositive cows as compared to seropositive calves born from seronegative cows. However, in this study, blood collection from calves was performed during the first month after birth, which affected the results due to the transmission of immunoglobulin through the colostrum, so it was not possible to verify the immune response in these calves. It is noteworthy that in the conditions found in the field we assume that calves usually feed from their own mothers. Vianna et al. (2008) found positive serology of $36.8 \%$ in fetuses from $N$. caninum seropositive cows.

A total of $29.12 \%$ of calves positive for $N$. caninum serology from negative cows show an infection ratio from the environment that suggests a careful analysis. In endemic conditions, the oocytes may be found in the pastures and in the water. The definitive host and other native species of the region favor the maintenance of the agent in the environment. This combined with a lack of control of the disease on the farm and the discarding of the carcasses of dead animals in the field favor the persistence of the risk factors associated with contamination.

The extraction rates of heifers that were either seropositive or seronegative for $N$. caninum were 28.24 and $50.12 \%$, respectively, which shows a reduction of $21.88 \%$ in the extraction rate of $N$. caninum seropositive heifers $(\mathrm{p}<0.0001)$. When compared with weaning and natality indexes of beef cattle herds that are raised in native pastures in the Pantanal, which are considered low in relation to dense and covered tropical regions of the country, the values for $N$. caninum seropositive heifers are close to 50 and $58 \%$, as found by Brasil (1978) and Cadavid Garcia $(1981,1986)$.

When the extraction rate of $N$. caninum seropositive heifers is considered, we observe a strong reduction capable of causing impact in the reproductive system, to a degree that varies according to the age of the female.

In Brazilian bovine herds a discard system that considers the $N$. caninum serology of the animal is not in place. In this study we found that cows seropositive for $N$. caninum are 1.44 times more prone to lose calves than are seronegative cows. The risk of abortion for cows infected with $N$. caninum was 1.7, and 3 to 7 times higher in seropositive cows as compared to seronegative cows (THURMOND; HIETALA, 1997).

Due to differences in the effect of risk factors associated with abortion in beef and dairy cattle observed in different regions and handling conditions, control strategies should be diversified and adopted based on the cost/benefit analysis for the reproductive system. In this case, the parameters to be considered are the production system, the handling conditions, the prevalence of the disease in the herd, the predominant transmission route, the existence of biosecurity measures in the propriety, and the effects of infection calculated in the productive and reproductive performance (DUBEY; SCHARES; ORTEGA-MORA, 2007).

Our results show that the reproduction of $N$. caninum seropositive primiparous cows has an impact of $44 \%$ in relation to seronegative heifers, which suggests the need for controlling 
Table 1. Association between $N$. caninum seroprevalence in heifers, reproductive status, and conception.

\begin{tabular}{|c|c|c|c|c|c|}
\hline \multirow[t]{2}{*}{ Heifers } & \multicolumn{2}{|c|}{ Reproductive status } & \multicolumn{2}{|c|}{ Conception } & \multirow[t]{2}{*}{ Extraction rate } \\
\hline & Pregnant (\%) & Not pregnant (\%) & Conceived & Did not conceive & \\
\hline Seropositive & $303(44.11)$ & $384(55.89)$ & 194 & 493 & $28.24 \%$ \\
\hline Seronegative & $243(59.12)$ & $168(40.88)$ & 206 & 205 & $50.12 \%$ \\
\hline Total & $546(49.73)$ & $552(50.27)$ & 400 & 698 & $36.43 \%$ \\
\hline
\end{tabular}

Table 2. Seroprevalence of anti-Neospora caninum antibodies as determined by RIFI in calves born from Neospora caninum seropositive or seronegative heifers.

\begin{tabular}{lccc}
\hline \multirow{1}{*}{ Heifers } & \multicolumn{2}{c}{ Calves } & Prevalence \\
\cline { 2 - 3 } & Seropositive & Seronegative & \\
\hline Seropositive & 131 & 63 & $67.53 \%$ \\
Seronegative & 60 & 146 & $29.12 \%$ \\
\hline Total & 191 & 209 & $47.75 \%$ \\
\hline
\end{tabular}

$\chi_{\mathrm{b}}^{2}=57.518$, where $\chi_{\mathrm{b}}^{2}$ is the relation between serologic diagnosis of

$N$. caninum among calves and their mothers, with degree of significance $(\mathrm{p}<0.0001)$. Serologic exam: RIFI $(1: 50)$.

the herds in the Pantanal region. The existence of flooding areas and wild animals, especially canids, should be further investigated to evaluate whether they are risk factors for this disease.

Losses during gestation may be the consequence of misdiagnosis of gestation, abortion, absorption of the embryo, or occurrence of infectious diseases that affect reproduction. Presence of neosporosis in this animal category in the system of beef cattle in the Pantanal contributes for a lower extraction rate of the herd. Thus, developing measures for the control of neosporosis in this animal category is very important.

In beef cattle herds of the Pantanal of South Mato Grosso, presence of $N$. caninum seropositive heifers causes a significant impact on reproduction, with a reduction of $21.88 \%$ in the extraction rate of the herd. Thus, we would like to highlight the importance of performing evaluations and procedures to control this disease in the herd, of establishing a control mechanism for buying and introducing new animals, and of the use of serology for $N$. caninum as an indication for the discarding of animals in bovine herds.

\section{Acknowledgments}

The authors would like to express their thanks for the funding of this project, which was provided by the Universal proposal of CNPq.

\section{References}

ALVAREZ-GARCIA, G. et al. Influence of age and purpose for testing on the cut-off selection of serological methods in bovine neosporosis. Veterinary Research, v. 34, n. 3, p. 341-352. 2003.

ANDERSON, M. L. et al. Evidence of vertical transmission of Neospora sp. infection in dairy cattle. Journal of the American Veterinary Medicine Association, v. 210, n. 8, p. 1169-1172, 1997.
ANDERSON, M. L. et al. Neospora-like protozoan infection as a major cause of abortion in California dairy cattle. Journal of the American Veterinary Medicine Association, v. 198, n. 2, p. 241-244, 1991.

ANDREOTTI, R. et al. Evidence of Neospora caninum in beef cattle and dogs in the state of Mato Grosso do Sul, Center-Western Region, Brazil. [Evidência de Neospora caninum em gado de corte e em cães no estado de Mato Grosso do Sul, região centro-oeste, Brasil.] Revista Brasileira de Parasitologia Veterinária, v. 13, n. 3, p. 129-131, 2004.

BARR, B. C. et al. Neospora-like protozoal infections associated with bovine abortions. Veterinary Pathology, v. 28, n. 2, p. 110-116, 1991.

BARR, B. C. et al. Neospora-like protozoal infections associated with abortion in goats. Journal of Veterinary Diagnostic Investigation, v. 4, n. 3, p. 365-367, 1992.

BRASIL. Ministério do Interior. Estudo de desenvolvimento integrado da bacia do Alto Paraguai: relatório de pré-diagnóstico. Brasília, DF, $1978.506 \mathrm{p}$.

CADAVID GARCIA, E. A. Estimativa dos custos de produçáo da pecuária de corte do Pantanal Matogrossense. Corumbá: EmbrapaUEPAE, 1981. 75 p. (Circular Técnica, 5).

CADAVID GARCIA, E. A. Estudo técnico-econômico da pecuária bovina de corte do Pantanal Mato-grossense. Corumbá: Embrapa CPAP, 1986. 150 p. (Documentos, 4).

DUBEY, J. P.; SCHARES, G. Diagnosis of bovine neosporosis. Veterinary Parasitology, v. 141, n. 1-2, p. 1-34, 2006.

DUBEY, J. P.; SCHARES, G.; ORTEGA-MORA, L. M. Epidemiology e control of neosporosis and Neospora caninum. Clinical Microbiology Reviews, v. 20, n. 2, p. 323-367, 2007.

DUBEY, J.P. et al. Newly recognized fatal protozoan disease of dogs. Journal of the American Veterinary Medical Association, v. 192, n. 9 , p. 1269-1285, 1988.

GONDIM, L. F. et al. Coyotes (Canis latrans) are definitive hosts of Neospora caninum. International Journal for Parasitology, v. 34, n. 2, p. 159-161, 2004.

HADDAD J. P.; DOHOO I. R.; VANLEEWEN J. A. A review of Neospora caninum in dairy and beef cattle - a Canadian perspective. Canadian Veterinary Journal, v. 46, n. 3, p. 230-243, 2005.

INNES, E. A. et al. The host-parasite relationship in bovine neosporosis. Veterinary Immunology and Immunopathology, v. 108, n. 1-2, p. 29-36, 2005.

INNES, E. A.The host-parasite relationship in pregnant cattle infected with Neospora caninum. Parasitology, v. 134, p. 1903-1910, 2007.

LEVINE, D. M.; BERENSON, M. L.; STEPHAN, D. Estatística: teoria e aplicaçóes. Rio de Janeiro: LTC, 2000. 811 p. 
LINDSAY, D. S.; DUBEY, J. P.; McALLISTER, M. M. Neospora caninum and the potential for parasite transmission. Compendium on Continuing Education for the Practicing Veterinarian, v. 21, n. 4, p. 317-321, 1999.

MARSH, A. E. et al. Neosporosis as a cause of equine protozoal myeloencephalitis. Journal of the American Veterinary Medical Association, v. 209, n. 11, p. 1907-1913, 1996.

McAlLISTER, M. M. et al. Dogs are definitive hosts of Neospora caninum. Internacional Journal for Parasitology, v. 28, n. 9, p. 1473-1478, 1998.

OLIVEIRA, J. M. et al. Prevalence of anti-Neospora caninum antibodies in dogs in the urban area of Campo Grande, MS, Brazil. Revista Brasileira Parasitologia Veterinária, v. 13, n. 4, p. 155-158, 2004.

OSHIRO, L. M. et al. Prevalence of anti-Neospora caninum antibodies in cattle from the state of Mato Grosso do Sul, Brazil. Revista Brasileira de Parasitologia Veterinária, v. 16, n. 3, p. 133-138, 2007.

PARÉ, J.; THURMOND, M. C.; HIETALA, S. K. Congenital Neospora caninum infection in dairy cattle and associated calfhood mortality. Canadian Journal of Veterinary Research, v. 60, n. 2, p. 133-139, 1996.

PAZ, G. F.; LEITE, R. C.; ROCHA, M. A. Associaçấo entre sorologia para Neospora caninum e taxa de prenhez em vacas receptoras de embrióes. Arquivo Brasileiro de Medicina Veterinária e Zootecnia, v. 59, n. 5 , p. 1323-1325, 2007.

PITEL, P. H. et al. Neosporosis in bovine dairy herds from the west of France: detection of Neospora caninum DNA in aborted fetuses, seroepidemiology of $N$. caninum in cattle and dogs.Veterinary Parasitology, v. 102, n. 4, p. 269-277, 2001.
SAMPAIO, I. B. M. Estatística aplicada à experimentaçáo animal. 3. ed. Belo Horizonte: Fundação de Estudo e Pesquisa em Medicina Veterinária e Zootecnia, 2007.

THORNTON, R. N.; THOMPSON, E. J.; DUBEY, J. P. Neospora abortion in New Zealand cattle. New Zealand Veterinary Journal, v. 39, n. 4, p. 129-133, 1991.

THURMOND, M. C.; HIETALA, S. K. Effect of congenitally acquired Neospora caninum infection on risk of abortion and subsequent abortions in dairy cattle. American Journal of Veterinary Research, v. 58, n. 12, p. 1381-1385, 1997.

THURMOND, M.C.; HIETALA, S. K. Culling associated with Neospora caninum infection in dairy cows. American Journal of Veterinary Research, v. 57, n. 11, p. 1559-1562, 1996.

VIANNA, L. C. et al. Incidence and transplacental transmission of Neospora caninum in primiparous females from Bos indicus slaughtered in Presidente Prudente, São Paulo, Brazil. Semina: Ciências Agrárias, v. 29, n. 2, p. 387-392, 2008.

Von BLUMRÖDER, D. et al. Comparison and standartisation of serological methods for the diagnosis of Neospora caninum infection in bovines. Veterinary Parasitology, v. 120, n. 1-2, p. 11-22, 2004.

WILLIAMS, D. J. L. et al. Neospora caninum associated abortion in cattle: the time of experimentally-induced parasitaemia during gestation determines foetal survival. Parasitology, v. 121, p. 347-358, 2000, (parte 4).

WOUDA, W. et al. Seroepidemiological evidence for a relationship between Neospora caninum infections in dogs and cattle. International Journal of Parasitology, v. 29, n. 10, p. 1677-1682, 1999. 